The 16th Economic International Conference

New Challenges and Opportunities for the Economy 4.0,

May 7-8th, 2020, Suceava, Romania

\title{
Adapted Techniques for Protecting Traditional Buildings
}

\author{
Ionuț DOHOTARIU, Andrei PURCARU
}

https://doi.org/10.18662/lumproc/ncoe4.0.2020/33

How to cite: Dohotariu, I., \& Purcaru, A. (2020). European Structural Funds and Rentability. In C. Nastase (vol. ed.), Lumen Proceedings: Vol. 13. 16th Economic International Conference NCOE 4.02020 (pp. 368-376). Iasi, Romania: LUMEN Publishing House.

https://doi.org/10.18662/lumproc/ncoe4.0.2020/33 


\title{
Adapted Techniques for Protecting Traditional Buildings
}

\author{
Ionuț DOHOTARIU1, Andrei PURCARU²
}

\begin{abstract}
The variations of morpho-spatial and formal modelling within the local / regional architecture typologies are determined not only by specific microclimatic elements (plain field or hills), but also by numerous other conditionings such as the type and use of local building materials. Nowadays, low quality modern materials and the effects of poorly understood modernization have a negative impact on the environment and the rural ambience. The traditional houses have taken over, perfected and diversified over time the repertoire of construction systems and execution techniques developed in the previous stages. Using traditional techniques in the process of built heritage restauration is synonymous with its adaptation to the contemporary comfort requirements and to the fulfilment of the exigencies of resistance and stability. The main constituent elements of the traditional building systems leads us to the analyzing the houses on subassemblies: the roof (roof frame and covering), walls, foundations and socle, carpentry and opening. Proper repair of traditional houses must be carried out accurately, taking into account the fact it is imperative to use good quality materials that prove effective during the reconstruction process. Beyond the importance and cultural relevance of the traditional house, the compatibility of materials is a complex and thorny process that involves a lot of responsibility.
\end{abstract}

Keywords: traditional architecture; vernacular building materials; Bukovina.

\footnotetext{
1 "G.M. Cantacuzino" Architecture Faculty, part of "Gheorghe Asachi" Technical University of Iaşi, Iaşi, Romania.

Architecture Doctoral School (SDA) of "Ion Mincu" University of Architecture and Urbanism, Bucharest, Romania. e-mail address: i.dvdohotariu@gmail.com

2 "G.M. Cantacuzino" Architecture Faculty, part of "Gheorghe Asachi” Technical University of Iaşi, Iaşi, Romania. e-mail address: andrei.purcaru@gmail.com
} 
Climatic constraints have imposed adequate formal types, expressions of some activities and ways of life in traditional Romanian architecture. The variations of morpho-spatial and formal modeling within the local / regional architecture typologies are determined not only by specific microclimatic elements (plain field or hills), but also by numerous other conditionings such as the type and use of local building materials. [1]

The materials and structural solutions traditionally used in southern Bukovina were not only determined by natural conditions, but also by social relationships and the material well-being of the inhabitants.

The predominant building materials are:

- Softwood - especially fir, used for walls and roofs;

- Stone - used for making bases and cellars;

- Clay - used for cob walls ("paiantă") and plasters.

- Short and long shingles ("draniţă") are used for roofing (less often straws and reeds)

The economic evolution of the communities proceed to use bricks (for walls) and ceramic tiles (for roofing). The use of materials manufactured in industrial processes, such as slaked lime paste (calcium hydroxide - "var stins pastă"), brick, ceramic tile or glass, are directly determined by the level of economical development of the communities. An influencing factor in the evolution of Bucovina's dwelling architecture was the strong connection with the Austro-Hungarian Empire, through which foreign constructive elements have entered the province. [2]

In particular, the new settlers (brought here mostly from the German environment: Franconia, Swabia and the Rhineland, except the Czechs and Slovaks), formed the so-called "German spirit" which, in the given development conditions of technology and traditional crafts in the villages, have exerted more than a century of permanent influence over the traditional architecture. Although this process affected almost all the constitutive parts of the house, the foreign influence did not replace the old Romanian building technique, but developed over the autochthonous/ local pattern. [1]

Thus, unlike the low house, specific to the medieval era, more and more high houses are being built compactly on the high stone foundation, without porch ("prispa"), replaced, more and more frequently with a wooden verandah ("cerdac"). Also, the roof, once high, with steep slopes, is now proportionated to the dimensions of the wooden walls, in which the horizontal beams ("cununi de bârne") ended in straight, "German" joints ("cheotori $<<$ nemțeşti $>>$ "); all this was possible thanks to improved 
woodworking techniques - this type of walls can be done only from faceted beams. In the villages situated near trade routes between the "Old Kingdom" and the Empire, especially those around Moldova's and Suceava's river valleys, the entry of foreign innovative elements was also due to imports; the merchants were bringing in manufacturing goods from abroad, such as: iron nails for shingles (they have completely replaced wooden nails and even the "gypsy" ones - "cuiele țigăneşti"), tiles, hobs, glass, hinges, door locks, padlocks and other household items. [2] The mastery of local craftsmen, driven by the technical progress of the time, was perfected with the increased level of civilization in the villages, leading to a new step in the evolution of traditional wooden architecture. [3] Thus, the art of woodworking has diversified itself into new expressions that have increased the resistance to borrowing new elements, creating therefore a framework for enriched original motifs, some of rare beauty. For construction, the wood essences were carefully chosen, each species being used according to its properties (type of fiber, strength, weight, appearance or ease of processing). Hardwood beams were prepared for socle ("tălpi”) and walls, then rafters, bindings, planks and shingles made out of fir wood; beech wood was being used for latches, window crosses and sometimes the ceiling floor and wall nails. [4] Linden was especially used for doors because it is light; elm or yew wood was used for nails, shingles or bindings. The wood for the house was prepared long before the building began. The beams were cut in the cold season, when they have less sap and are easier to exploit (late autumn or spring).

Similar to Bukovina, until the 18th century, the Saxon houses were being made out of wood as the main material; Since 1850s, the Saxon brick house became widespread. [5] Currently, the building materials used are brick, stone and wood. Stone is used both for the masonry of the walls and for the groundwork, and brick especially for the walls. The roof covering is made out of ceramic tiles. Lately, the number of low quality brick houses with tin roofs or concrete tiles has increased. [6]

In the past, throughout Moldova, to the east and the west of the Prut river, people built from materials considered ecological today: raw earth ("ceamur") for houses, outbuildings and social constructions (schools, cultural center, inns), wood for places of worship, stone -rarely for houses and outbuildings and quite often for churches. For the construction of raw earth houses, a clay roll ("vălătuc") was used on a wood structure ("furci"), by beating the ceamur in successive layers. More recently, at the beginning of the 20th century, adobe was used. The oldest types of roofs, still stand the test of time especially in villages from Botoşani county, were the vegetal ones, made of cereal straw, reed and shingles (“draniţă / şiţă / şindrilă’). [7] 
In the Transylvanian Plain, the main construction material used to be the oak wood, but the structure is made of wooden frames placed on large beams ("tălpi"). The space between the frames was filled with braid or clay wadding. Clay and mud were used in all possible forms (adobe, cob etc.). The quarry stone is rarely used, instead river stone is frequent in the area. After 1900, there are similarities between the architecture from the Transylvanian Plain and the Saxon influence area of Năsăud - Bârgău in terms of using brick for walls, columns and arches, as well as the roofs made of straw, ceramic tiles and shingles. [8]

Nowadays, low quality modern materials and the effects of poorly understood modernization have a negative impact on the environment and the rural ambience; e.g:

- traditionally, interior and exterior plasters were made on a network of wooden slats using mortars based on sand and lime. These have been replaced with sand / cement based plasters and gypsum cardboard (used outdoors and indoors) that increase the rate of depreciation in the perishable traditional mortar substrates.

- natural wood floors (floor boards, wooden parquet etc.) have been replaced with laminate flooring, a synthetic, non-ecological and vapor-impermeable material;

- exterior and interior finishes of walls and ceilings, based on natural lime, have been completely replaced, with synthetic materials such as washable or oil-based paints, losing an important source of health for residents; natural lime based finishes have a bactericidal and antifungal effect, preventing water accumulation inside the walls by regulating moisture.

- thermal insulation for ceilings, attics, floors, initially made with traditional, ecological materials, have been replaced with thermally efficient synthetic materials or compounds that no longer have qualities of generating healthy living conditions. The use of polystyrene as a thermal insulator for wooden beam walls alters the durability of the construction. [6]

The need for classification in presenting the main constituent elements of the traditional building systems leads us to the analyzing the houses on subassemblies: the roof (roof frame and covering), walls, foundations and socle, carpentry and opening. Proper repair of traditional houses must be carried out accurately, taking into account the fact it is imperative to use good quality materials that prove effective during the reconstruction process. Beyond the importance and cultural relevance of the 
traditional house, the compatibility of materials is a complex and thorny process that involves a lot of responsibility. We can say that there are no perfect recipes, but only a few general sketches ready to be adapted for each case.

\section{THE ROOF}

The frame will be repaired using exclusively wood, only using traditional local techniques and joints (or starting from local technologies), as much as possible, by involving local carpenters. By using renewable natural materials wherever possible, any negative effects on the construction will be virtually eliminated. Organic materials resulting from polymerization processes should not be used, as they change their qualities over time (strength, torsion, flow) due to environmental conditions (repeated freezing / thawing process, ultraviolet radiation, summer / winter temperature variations). However, it is possible to use other materials obtained by contemporary technological means: CLT, lamellar wood, cross-laminated wood. It should be noted that the use of these new materials facilitates the creation of large wooden pieces with various geometries and outstanding performance, thus avoiding slaughtering secular trees. [9]

Whenever a roof needs to be completely rebuilt, its slope must be chosen accordingly to the local specificity and the technical specifications of the constitutive material; if possible and desirable, the interior space generated by the roof structure can be used to incorporate different usable spaces. For all wooden elements, fireproofing and biological protection coating will be carried out using substances that do not affect its structure and color, allowing a subsequent treatment with wax, oils and natural solutions. If there are ornaments on the roof or on the fascia board, they will adopted unaltered, but in a simplified form, keeping the local specificity. The roof of the dormers will occupy a maximum $15 \%$ of the surface of the slope on which they will be located, being simultaneously dimensioned and positioned to keep a consistent image specific to the place; it is necessary that they do not constitute a discrepant element, visible from the street or from various belvedere points known locally. [9]

\section{THE WALLS}

It is recommended to be made out of renewable materials and / or materials considered traditionally local (wood, clay, adobe, stone, brick, even if its use in the area is recent). The extraordinary quality of wood is that, due to its high calorific value (second in value after water) it has practically the same "thermal mass as stone or clay", but it is at least 7 times better thermal 
insulator than these or other materials used in masonry (brick, lightweight concrete blocks, autoclaved aerated concrete (AAC) etc.). [6]

As a general principle, it is necessary to try finding solutions compatible with the existing materials, that do not negatively influence the structure and behavior in time (taking into account the seismic area in which the construction falls), while maintaining a consistent part of the original structure intact. Large areas of walls that prevent the transfer of water vapors will not be made, this phenomenon having as direct effects the appearance of dampness and molds, implicitly shortening the life of the construction. The load-bearing stone or brick masonry will be plastered with lime / sand-based mortar to allow water to be absorbed, circulated and evaporated at a normal rate. The walls should be treated to diminish / prevent the capillary rise of water, in the event waterproofing the entire surface of the foundation is not recommended. Partition walls shall be constructed of renewable materials that are predominantly considered traditional locally (wood, brick), environmentally friendly or eco-sustainable materials (wood, brick, clay / mud, hemp, wool, straw, sawdust or conglomerates with natural binders) for spaces that allow this composition. [9]

When working on existing constructions, if the technical expertise reveals the need for consolidation, the architect will propose solutions involving the use of traditional materials and techniques (local masonry repairs, insertion of new structural elements of wood or stone, wall thickening etc.) or $21^{\text {st }}$ century techniques that use renewable materials (cross-laminated wood, lamellar wood, multilayer wood boards etc.). For the repair / restoration of stone walls, it is recommended to use stone obtained from local quarries or from pre-existing sources (recycling materials from demolitions) and the use of mortar based slaked lime (hydraulic). In the case of wood, it is recommended to reuse old undamaged wood, recovered from dismantled outbuildings or certified organic wood, which comes from sustainably managed forests, according to economic and ecological criteria.

Wooden walls: the damaged parts will be replaced with identical parts, made of wood of the same essence, in order not to intervene and unbalance the overall bearing capacity of the structure and its hygrothermal behavior. Wooden (or metal) stiffeners can be used for fastenings and connections. Fireproofing and biocidal coatings will be applied using only substances that do not affect the structure and color of the wood, allowing its subsequent treatment with wax, oil and natural solutions. [6]

Stone walls: interventions will be made with compatible, elastic materials, which will favor the transfer of vapors - mortars and lime-sand plasters, clay. The use of cement-based plasters that are not vapor permeable 
is not recommended. The stone will not be covered with varnishes and paints that influence its porosity and vapor permeability. The chosen materials shall be compatible with the type of stone used, being dependent on its degree of porosity. Brick walls: interventions will be made with compatible, elastic materials, which will favor the transfer of vapors: mortars and lime-sand / clay plasters. The use of cement based plasters that are not vapor permeable is not recommended. If the technical expertise establishes that structural reinforcements of the brick walls are necessary, reinforced concrete coating on the entire wall surface will be avoided; when this is not possible, additives may be used to increase its vapor permeability, in order to prevent the "bag" effect which will diminish the durability as well as the comfort of using the construction over time.

Cob walls ("paiantă"): interventions will be made with compatible, elastic materials, which will favor the transfer of vapors. Do not use cementcoated plasters that are not vapor permeable. Adequate compositions will be made to diminish / prevent capillarity.

\section{CARPENTRY AND OPENINGS}

The traditional proportions between width and height of the doors and windows will be observed, especially on the main and street facades, in order to give a stylistic unity to the street front. [4] It is recommended to alternate small openings of vernacular architecture with large, contemporary glazing, the size of a wall, for spaces that require proper lighting. Atypical openings will not be used: circle, triangle, rhombus, trapezoid, hexagon etc., which in operation can prove various vices / inconveniences like water infiltration or atypical shading solutions that are expensive and sometimes inefficient or unsightly. It is recommended to use wood (raw or laminated) and metal to make the carpentry. The carpentry can be single, with insulating glass, or double, with single glazing. The components of the carpentry (frames, window splashes, transoms) shall be made of wood or metal (exceptionally, for a certain compliance with the fire resistance regulations, which can not be obtained by using wood, metal may be used strictly in the locations required by law). [9]

In order to meet the current requirements regarding energy efficiency, the thermal insulation glazing will have two or three sheets of glass, using indirect means of ventilation, maintaining specific image of the buildings of this type. The windows and doors will be made of wood (solid or laminated) treated with linseed oil, waxed or painted with natural solutions, with metal hardware. Hardwood will be used for the exterior carpentry. In their fabrication, the traditional techniques will be employed and the craftsmen from the area will be involved, as much as possible. 
Valuable elements will be preserved and reconditioned using the same materials and construction techniques (both elements with typical shapes and those with atypical shapes), or will be replaced, without changing any specific division or details of the carpentry. PVC or metal will be replaced with solid or laminated wood joinery. [5] To increase the comfort and thermal insulation, whenever a window is single glazed, it will be doubled inside the house with a new frame helding an insulating glass (two or three sheets), with a single wing (without splashes), so that the intervention is not observed from the outside.

\section{FOUNDATIONS}

Recommended materials are stone, cyclopean concrete, brick and concrete (provided that foundations are made under load-bearing walls). The cellars and vaults will be made mainly of brick and / or stone, bound with lime / sand based mortar. For the stone socles, local materials will be used, with local technologies and labor, by activating the craftsmen from the area. Do not excessively use cement (especially Portland cement, especially without constructive expansion joints provided in the project) as a working material or as a base material for binder. [5] Starting with the middle of the twentieth century, cement has been used as a binder for stone foundations, although it is not the best solution. Cement is a harder material than most rocks and considering water infiltration (the foundation is exposed on average to 40 freeze / thaw per year), the concrete will grind the surface of the rock with which it is in contact. Thus, the stone deteriorates faster than the binder.

The waterproofing and thermal insulations will not cover the entire infrastructure: barriers can be made against capillarity, by injections with special mortars and by using plasters consisting of special sanitation mortars, drainage layers can be created to facilitate the water removal from the foundation, thus prevent infiltration and degradation. The perimeter sidewalk (if necessary) will be repaired / built (if necessary) to remove rainwater from construction's foundation. The foundations of the old houses seem to be "dry", an aspect conferred by the grinding and falling of the binder between the stone elements. These foundations can be reconditioned by cleaning and refilling the joints with hydraulic mortar or lime based mortar with additives (stone dust).

Traditional buildings are made of permeable materials that allow the buildings to breathe. Thus, through masonry, slabs / floors and even carpentry, there is a very slow transfer of air and water vapors from inside to outside, a transfer that helps maintaining a healthy atmosphere inside the building. The traditional houses have taken over, perfected and diversified 
over time the repertoire of construction systems and execution techniques developed in the previous stages.

Within this evolutionary process, a series of general principles were perpetuated, regarding the efficient capitalization of the local resources like construction materials, the adaptation of construction systems to the seismicity of the area and the plastic expression of the load-bearing structure. Therefore, traditional materials, either mineral (inorganic) or organic (vegetal or animal origin), have particularly proved important common characteristics, which make them clearly superior in terms of ecology and sustainability over the synthetic materials. [6] Thus, the materials originating and forming in the natural environment are particularly resistant to the action of ultraviolet solar radiation that causes rapid degradation of any synthetic material (PVC, polystyrene, polyurethane, agglomerating resins, compounds of synthetic paints etc.). Natural materials are environmentally friendly and durable, so it is advisable, as far as possible, to maintain the use of natural materials in traditional homes - wooden floors, wooden carpentry painted with natural paints, plaster and wall paints based on lime etc. Also, given the fact reducing environmental pollution is a global concern, all these materials are proving to be more environmentally friendly than modern ones, and at the same time more sustainable.

\section{References}

[1] Ionescu G. Romanian popular architecture. Bucharest: Meridiane Publishing House; 1971.

[2] Cojocaru N. The old wooden house of Bukovina. Popular architecture. Bucharest: Meridiane Publishing House; 1983.

[3] Stoica G. Interior architecture of the peasant house. Râmnicu Vâlcea; 1974

[4] Romanian Village Dwelling: studies of traditional architecture for preserving and capitalizing by typification, Revised and completed edition, ICCPDC, Bucharest, 1989.

[5] Huelsemann J. The Peasant house from Transylvania. Sibiu: Simetria Publishing House; 2014.

[6] Miron C. Unconventional local materials for sustainable energy. Iaşi: INCD URBAN INCERC; 2012.

[7] ***. Botoşani's cultural traditions. Botoşani County Center for the promotion of traditional culture. Botoşani: Axa Publishing House; 2008

[8] Mureşanu P. Contributions to the study of peasant settlements and constructions in the Transylvanian Plain. The Yearbook of the Ethnographic Museum of Transylvania, 1965 - 1967. Cluj-Napoca; 1969.

[9] OAR. Architectural guides for compliance with the local specifics of the rural environment 